UDC 544.344; 577.1.08

\title{
STUDY OF CATALASE ACTIVITY OF BIOMIMETIC SENSORS AT DIFFERENT TEMPERATURES AND AMOUNTS OF SMART MATERIAL
}

\author{
N.N.Malikova, N.I.Ali-zade, T.M.Nagiev \\ M.Nagiev Institute of Catalysis and Inorganic Chemistry NAS of Azerbaijan \\ tnagiev@azeurotel.com
}

Received 13.01.2021

Accepted 26.02.2021

\begin{abstract}
Biomimetic sensors based on semiconductor $(\mathrm{Si})$, metal $(\mathrm{Al})$ and smart material $\left(\mathrm{TPhPFe}{ }^{3+} \mathrm{OH} / \mathrm{Al}_{2} \mathrm{O}_{3}\right)$ have been developed. It has been found that a biomimetic sensor, where a semiconductor ( $\mathrm{Si}$ ) is used as an electrode, exhibits high sensitivity, stability and reproducibility. The effect of temperature and the amount of smart material on the catalase activity of biomimetic sensors was studied. At the study of the $\mathrm{Si}$-electrode for catalase activity, it was revealed that the amount of smart material and temperature do not affect the detection limit of hydrogen peroxide in an aqueous solution, the sensitivity threshold, which was $10^{-6}$ mass $\%$. When detecting the catalase activity of the $\mathrm{TPhPFe} \mathrm{P}^{3+} \mathrm{OH} / \mathrm{Al}_{2} \mathrm{O}_{3} / / \mathrm{Al}$ biomimetic sensor, it was established that the sensitivity threshold was also $10^{-6}$ mass $\%$.
\end{abstract}

Keywords: biomimetic, sensor, tetraphenylporphyrin of iron, catalase, semiconductors, smart material.

doi

\section{Introduction}

Determination of the concentration of hydrogen peroxide is very important in various fields, including medicine, in the textile industry, the cosmetic industry, for environmental control, etc. In this regard, based on bioimitation modeling of the known catalase, peroxidase and monooxygenase processes, it is possible to synthesize biomimetic analogs of the corresponding enzymes, the use of which in sensors will eliminate many of the above disadvantages. In works $[1,2]$ the results of research in this direction are given.

Developed on the basis of a smart biomimetic material (iron tetraphenylporphyrin) and a semiconductor - $\mathrm{Si}$, the biomimetic sensor is characterized by long-term stability, high sensitivity and reproducibility, with the possibility of expanding the range of detectable trace concentrations of $\mathrm{H}_{2} \mathrm{O}_{2}$ in an aqueous solution. The sensitivity threshold was $10^{-6}$ mass $\%[3,4]$.

To detect trace concentrations of $\mathrm{H}_{2} \mathrm{O}_{2}$ in aqueous solutions, we have created and developed the simplest and cheapest to use potentiometric biomimetic sensors with rapidity and high sensitivity. An experiment carried out with a metal, namely with aluminum, on the surface of which $\mathrm{TPhPFe}^{3+} \mathrm{OH} / \mathrm{Al}_{2} \mathrm{O}_{3}$ was applied, made it possible to determine the trace concentrations of $\mathrm{H}_{2} \mathrm{O}_{2}$ in an aqueous solution, the sensitivity threshold of which was $10^{-6}$ mass \% [5].

In the presented work, the effect of temperature and amount of smart material on the catalase activity of biomimetic sensors made of $\mathrm{Al}, \mathrm{Si}$ electrodes and a smart biomimetic catalyst $-\mathrm{TPhPFe}{ }^{3+} \mathrm{OH} / \mathrm{Al}_{2} \mathrm{O}_{3}$ was studied.

\section{Experimental part}

Catalase activity of biomimetic sensors was determined by potentiometric method. Two biomimetic $\mathrm{Si}$ electrodes were prepared with a working surface size of $0.3 \times 0.3 \mathrm{sm}$ and $0.6 \times$ $0.6 \mathrm{sm}$. The prepared biomimetic electrode contained an amount of smart material of 0.012 and $0.025 \mathrm{mg}$. To study the catalase activity, we used an extremely low concentration of $\mathrm{H}_{2} \mathrm{O}_{2}$. The results of experimental studies are shown in Figures 1 and 2.

Figure 1 shows the results of experimental studies of the catalase activity of a biomimetic electrode based on a Si-electrode and $\mathrm{TPhPFe}^{3+} / \mathrm{Al}_{2} \mathrm{O}_{3}$ smart material in amounts equal to 0.012 and $0.025 \mathrm{mg}$.

The observed jumps of the electrochemical potential at different amounts of smart material (while the temperature remained at $22^{\circ} \mathrm{C}$ ) have the same character (curves 1 and 2 in 
Figure 1), differing in the initial value of the potential.

For a biomimetic sensor containing 0.025 $\mathrm{mg} \mathrm{TPhPFe}^{3+} \mathrm{OH}$ (curve 1 ), this value is ($0.305 \mathrm{mV}$ ). The content of $0.012 \mathrm{mg}$ of smart material $-\mathrm{TPhPFe}{ }^{3+} \mathrm{OH}$ in the biomimetic sensor changes the initial value of the potential and is $(-0.14 \mathrm{mV})$

A change in the temperature of the reaction medium up to $40^{\circ} \mathrm{C}$ does not change the character of the curves (Figure 2, curves 1 and 2), and is reflected in the values of the electrode potential. For a biomimetic sensor with a content of $0.025 \mathrm{mg} \mathrm{TPhPFe}{ }^{3+} \mathrm{OH}$ (curve $1)$, this value is $(-0.131 \mathrm{mV})$. The content of $0.012 \mathrm{mg}$ of smart material $-\mathrm{TPhPFe}{ }^{3+} \mathrm{OH}$ in the biomimetic sensor changes the initial value of the potential and is $(-0.109 \mathrm{mV})$.

As a result of experimental studies, it was established that independently of the amount of $\mathrm{TPhPFe}^{3+} \mathrm{OH}$ smart material and temperature change, it does not affect the catalase activity of the biomimetic sensor. The sensitivity threshold is $10^{-6}$ mass \% [6].

It was interesting to conduct experiments and find out how low concentrations of $\mathrm{H}_{2} \mathrm{O}_{2}$ can be detected by an advanced biomimetic sensor based on an $\mathrm{Al}$ electrode, i.e., to determine its sensitivity threshold at different temperatures and amounts of smart material.

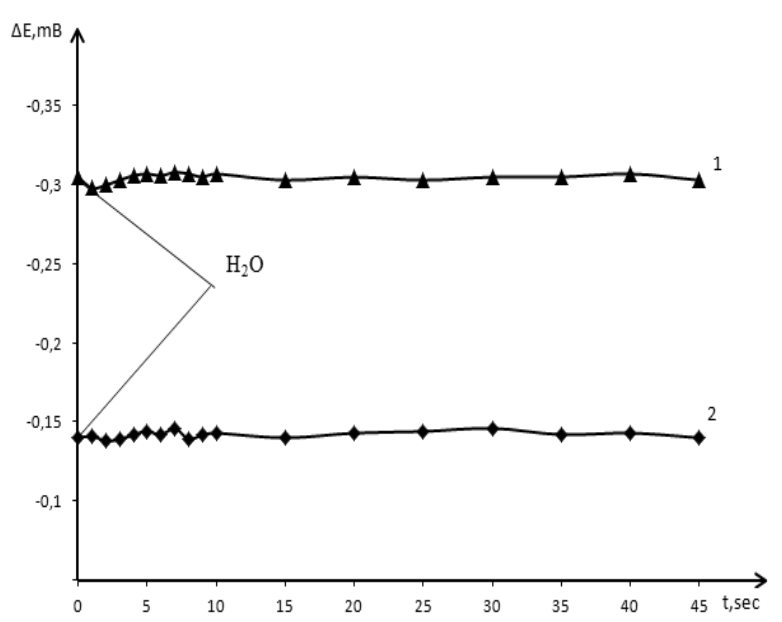

Fig. 1. Change in emf systems depending on time at low concentrations of $\mathrm{H}_{2} \mathrm{O}_{2}$ for $\mathrm{TPhPFe}{ }^{3+} \mathrm{OH} / \mathrm{Al}_{2} \mathrm{O}_{3} / /$ Si biomimetic sensor; $\mathrm{C}_{\mathrm{H}_{2} \mathrm{O}_{2}}=10^{-6}$ mass $\%$; $T=22^{0} \mathrm{C}$ : quantity $\mathrm{TPhPFe}{ }^{3+} \mathrm{OH}=0.025 \mathrm{mg}(1)$ and $0.012 \mathrm{mg}(2)$.
Continuing research on the study of the physicochemical characteristics of a biomimetic sensor, developed on the basis of a smart biomimetic material (iron tetraphenylporphyrin), characterized by long-term stability, high sensitivity and reproducibility, with the possibility of expanding the range of determined trace $\mathrm{H}_{2} \mathrm{O}_{2}$ concentrations in an aqueous solution, we prepared two biomimetic electrodes from $\mathrm{Al}$ with a working surface size of $0.3 \times 0.3 \mathrm{sm}$ and $0.6 \times 0.6 \mathrm{sm}$.

Prepared biomimetic electrodes contained 0.016 and $0.030 \mathrm{mg}$. of smart materialc.

Figures 3 and 4 show the experimental data obtained in the study of $\mathrm{H}_{2} \mathrm{O}_{2}$ at low concentrations in an aqueous solution depending on temperature.

As shown by the results of experiments carried out with $0.016 \mathrm{mg} \mathrm{TPhPFe}{ }^{3+} \mathrm{OH}$ containing electrode (curves 1, 2, 3, 4, Figure 3), the electrode potential of the background solution is $(0.562-0.565 \mathrm{mV})$. With this the temperature remained equal to $22^{0} \mathrm{C}$. And at a temperature of $30^{\circ} \mathrm{C}$ (Figure 4), the electrode potential of the background solution vade $(0.580-0.590 \mathrm{mV})$.

The amount of $\mathrm{TPhPFe}^{3+} \mathrm{OH}$ deposited on the surface of the $\mathrm{Al}$ electrode was $0.016 \mathrm{mg}$ in both cases.

Thus, the developed biomimetic sensor makes it possible to determine low concentrations of $\mathrm{H}_{2} \mathrm{O}_{2}$ in an aqueous solution. The sensi-

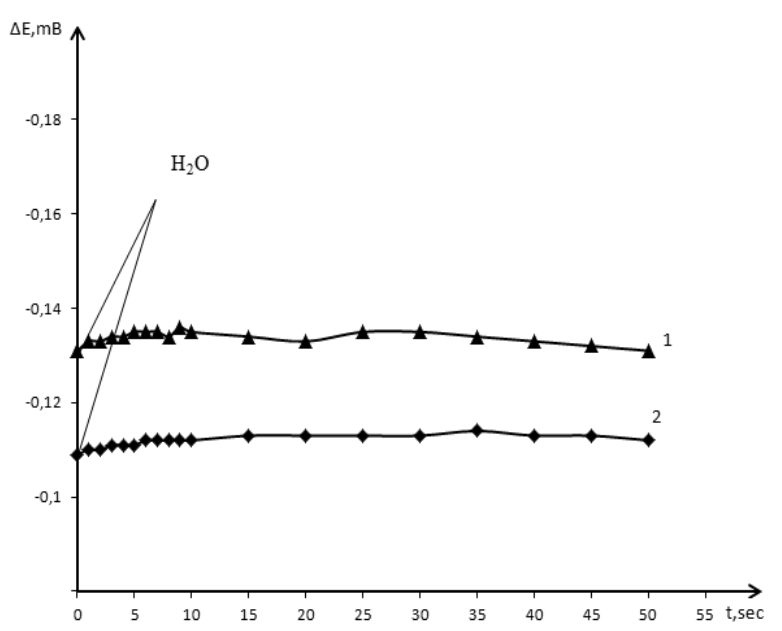

Fig. 2. Change in emf systems as a function of time at low concentrations of $\mathrm{H}_{2} \mathrm{O}_{2}$ for $\mathrm{TPhPFe}{ }^{3+} \mathrm{OH} / \mathrm{Al}_{2} \mathrm{O}_{3} / / \mathrm{Si}$ biomimetic sensor $\mathrm{C}_{\mathrm{H}_{2} \mathrm{O}_{2}}=10^{-6}$ mass $\%$. $T=40^{\circ} \mathrm{C}$; quantity $\mathrm{TPhPFe}^{3+} \mathrm{OH}=0.025 \mathrm{mg}(1)$ and $0.012 \mathrm{mg}(2)$. 
tivity threshold at these temperatures (22 and $30^{\circ} \mathrm{C}$ ) was $10^{-6}$ mass $\%$. Simultanously the effect of the amount of smart material in the reaction medium on the catalase activity of the developed biomimetic sensors was studied using the potentiometric method. To study the catalase activity of biomimetic sensors, an extremely low concentration of $\mathrm{H}_{2} \mathrm{O}_{2}$ was used. The experimental data are shown in Figure 5. The amount of $\mathrm{TPhPFe}{ }^{3+} \mathrm{OH}$ smart material $(0.016$ and $0.030 \mathrm{mg}$ ) does not affect the catalase activity of the biomimetic sensor and bears identical character with different background potentials. The initial value of the electrochemical poten-

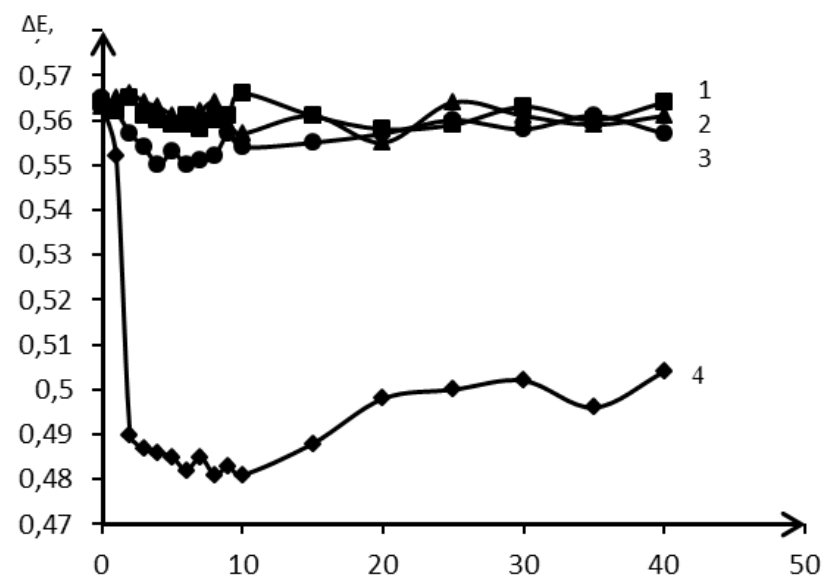

Fig. 3. Change in emf systems depending on time at low concentrations of $\mathrm{H}_{2} \mathrm{O}_{2}$ for $\mathrm{TPhPFe}{ }^{3+} \mathrm{OH} / \mathrm{Al}_{2} \mathrm{O}_{3} / / \mathrm{Al}$ biomimetic sensor. $T=22^{0} \mathrm{C}$. Quantity $\mathrm{TPhPFe}{ }^{3+} \mathrm{OH}=0.016 \mathrm{mg}$. $1-\mathrm{Al}+$ silver paste+ $\mathrm{TPhPFe}{ }^{3+} \mathrm{OH} / \mathrm{Al}_{2} \mathrm{O}_{3}\left(10^{-6}\right.$ mass \%), $2-\mathrm{Al}+$ silver paste+ $\mathrm{TPhPFe}{ }^{3+} \mathrm{OH} / \mathrm{Al}_{2} \mathrm{O}_{3}\left(10^{-4}\right.$ mass \%), 3 - $\mathrm{Al}+$ silver paste+ $\mathrm{TPhPFe}{ }^{3+} \mathrm{OH} / \mathrm{Al}_{2} \mathrm{O}_{3}\left(10^{-3}\right.$ mass \%), 4 - $\mathrm{Al}+$ silver paste+ $\mathrm{TPhPFe}{ }^{3+} \mathrm{OH} / \mathrm{Al}_{2} \mathrm{O}_{3}\left(10^{-2}\right.$ mass \%).

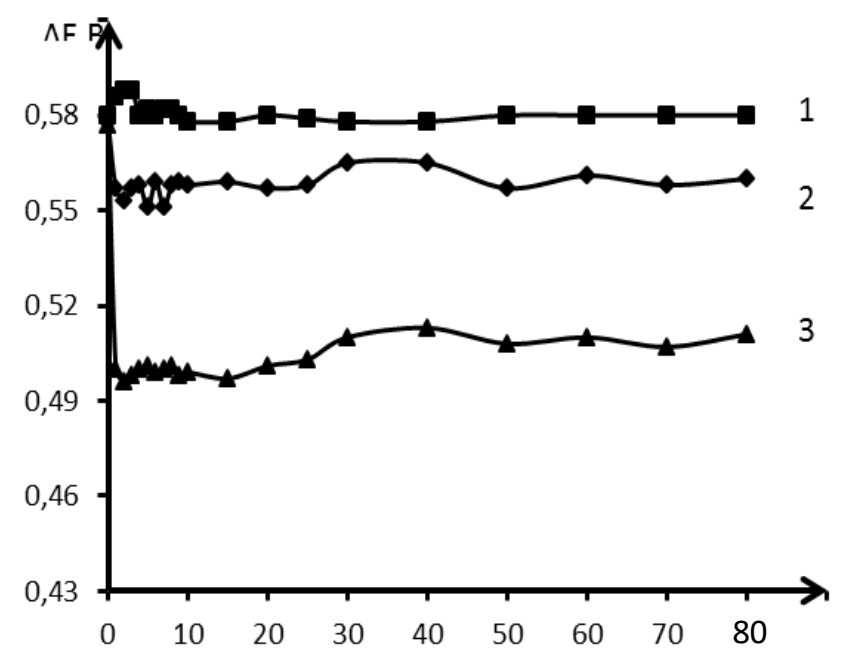

tial for a biomimetic sensor containing 0.016 $\mathrm{mg}$ (Figure 5) of smart material $\left(\mathrm{TPhPFe}^{3+} \mathrm{OH}\right)$ is $0.562-0.565 \mathrm{mV}$. However, for a biomimetic sensor containing $0.030 \mathrm{mg}$ of smart material $\left(\mathrm{TPhPFe}^{3+} \mathrm{OH}\right)$ the initial value of the electrochemical potential is in the range of $0.572-$ $0.581 \mathrm{mV}$.

Thus, there was synthesized an oxidation-resistant catalase-type biomimetic sensor based on the iron porphyrin complex. It was discovery that the developed biomimetic sensor can detect low concentrations of $\mathrm{H}_{2} \mathrm{O}_{2}$ (up to $10^{-6}$ mass \%) in an aqueous solution, regardless of the amount of smart material and temperature.

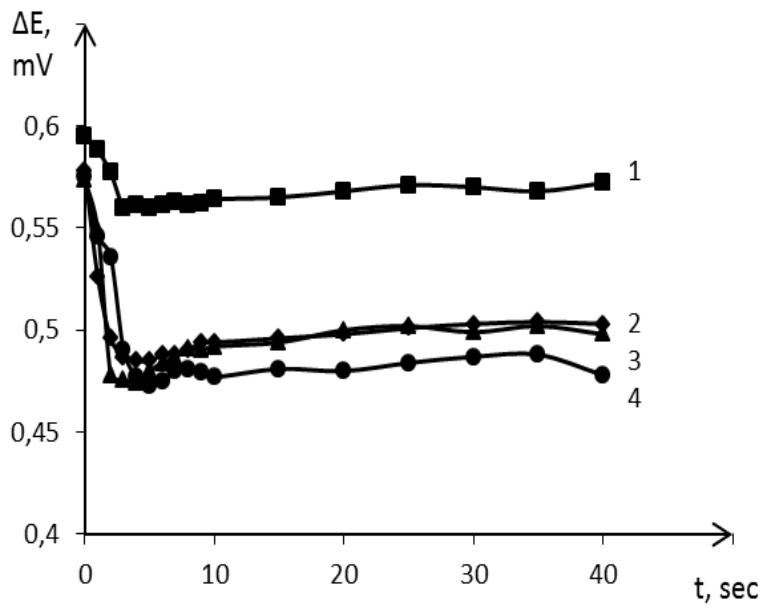

Fig. 4. Change in e.m.f. systems depending on time at low concentrations of $\mathrm{H}_{2} \mathrm{O}_{2}$ for $\mathrm{TPhPFe}{ }^{3+} \mathrm{OH} / \mathrm{Al}_{2} \mathrm{O}_{3} / / \mathrm{Al}$ biomimetic sensor. $T=30^{\circ} \mathrm{C}$. Quantity $\mathrm{TPhPFe}{ }^{3+} \mathrm{OH}=$ 0.016mg. $1-\mathrm{Al}+$ silver paste+TPhPFe ${ }^{3+} \mathrm{OH} / \mathrm{Al}_{2} \mathrm{O}_{3}$ $\left(10^{-6}\right.$ mass $\left.\%\right) ; 2-\mathrm{Al}+$ silver paste $+\mathrm{TPhPFe}^{3+} \mathrm{OH} / \mathrm{Al}_{2} \mathrm{O}_{3}$ $\left(10^{-4}\right.$ mass $\left.\%\right) ; 3-\mathrm{Al}+$ silver paste $+\mathrm{TPhPFe}^{3+} \mathrm{OH} / \mathrm{Al}_{2} \mathrm{O}_{3}$ $\left(10^{-3}\right.$ mass $\left.\%\right) ; 4-\mathrm{Al}+$ silver paste $+\mathrm{TPhPFe}^{3+} \mathrm{OH} / \mathrm{Al}_{2} \mathrm{O}_{3}$ $\left(10^{-2}\right.$ mass $\left.\%\right)$.

Fig. 5. Change in emf systems depending on time at low concentrations of $\mathrm{H}_{2} \mathrm{O}_{2}$ for $\mathrm{TPhPFe}^{3+} \mathrm{OH} / \mathrm{Al}_{2} \mathrm{O}_{3} / / \mathrm{Al}$ biomimetic sensor. $T=$ $22^{0} \mathrm{C}$. Quantity $\mathrm{TPhPFe}{ }^{3+} \mathrm{OH}=0.030 \mathrm{mg}$. $1-\mathrm{Al}+$ silver paste $+\mathrm{TPhPFe}{ }^{3+} \mathrm{OH} / \mathrm{Al}_{2} \mathrm{O}_{3}\left(10^{-6}\right.$ mass \%), $2-\mathrm{Al}+$ silver paste+ $\mathrm{TPhPFe}^{3+} \mathrm{OH} /$ $\mathrm{Al}_{2} \mathrm{O}_{3}\left(10^{-4}\right.$ mass \%), 3 - $\mathrm{Al}+$ silver paste + $\mathrm{TPhPFe}{ }^{3+} \mathrm{OH} / \mathrm{Al}_{2} \mathrm{O}_{3}\left(10^{-2}\right.$ mass \%). 


\section{References}

1. Nagiev T.M. Coherent Synchronized Oxidation by Hydrogen Peroxide. Amsterdam: Elsevier, 2007. 325 p.

2. Nagiev T.M. Biomimetic Based Application. Preface IX. Chapter 4. Croatia. INTECH. 2011. P. 105.

3. Melikova N.N., Ali-zade N.I., Nagiev T.M. Issledovanie katalaznoi aktivnosti biomimeticheskikh sensorov. Chemical Problems. 2018. T. 16. № 3. S. 437-443.

4. Malikova N.N., Ali-zadeh N.I., Nagiev T.M. Catalase-biomimetic sensor on base of electrochemical electrode TPhPFe(III)/ $/ \mathrm{Al}_{2} \mathrm{O}_{3} \mathrm{~Pb}$ and
$\mathrm{TPhPFe}(\mathrm{III}) / \mathrm{Al}_{2} \mathrm{O}_{3} \mathrm{Si}$. J. Chemistry and Chemical Engineering (USA), www.davidpublishing.com 2015. V. 9. No 1, January P. 67-70.

5. Malikova N.N., Ali-zadeh N.I., Nagiev T.M. Biomimetik sensors for determining trace concentrations of $\mathrm{H}_{2} \mathrm{O}_{2}$ in aqueous and aqueous-alcohol solutions. $8^{\text {th }}$ European Forum for Materials and Applications for Sensors and Transducers. Bratislava, Slovakia. 2019. September 2-5. Full text.

6. Melikova N.N., Ali-zade N.I., Nagiev T.M. Issledovanie katalaznoi aktivnosti biomimeticheskikh sensorov. Chemical Problems. 2018. № 3. T. 16. S. 437-443.

\section{MÜXTӘLIF TEMPERATUR VӘ SMART MATERALIN FORQLI MIQDARINDAN ASILI OLARAQ BİMIMETIK SENSORLARIN KATALAZ AKTIVLIYININ ÖYRəNILMəSI}

\section{N.N.Məlikova, N.İ.əli-zadə, T.M.Nağıyev}

Yarımkeçirici ( $\mathrm{Si})$, metal (Al) vo smart material $\left(\mathrm{TPhPFe}^{3+} \mathrm{OH} / \mathrm{Al}_{2} \mathrm{O}_{3}\right)$ əsasında biomimetik sensorlar işlənib hazırlanmışdır. Yarımkeçiricinin ( $\mathrm{Si}$ ) elektrod kimi istifadə olunduğu bir biomimetik sensorun yüksək həssaslıq, stabillik və təkrar istifadəsi göstərdiyi müəyyən edilmişdir. Temperaturun asıllığı və smart material miqdarının biomimetik sensorların katalaz aktivliyinə təsiri öyrənilmişdir. Si-elektrodun katalaz aktivliyini öyrənərkən müəyyən olunmuşdur, ki smart materialın miqdarı və temperaturun sulu məhlulda hidrogen peroksidin aşkarlanma həddini, $10^{-6}$ küt.\% təşkil edir. $\mathrm{TPhPFe}^{3+} \mathrm{OH} / \mathrm{Al}_{2} \mathrm{O}_{3} \mathrm{Al}$ biomimetik sensorun katalaz aktivliyini öyrənərək müəyyən olunmuşdur, ki həssaslıq həddi $10^{-6}$ küt.\% təşkil edir.

Açar sözlar: biomimetik, sensor, dəmir tetrafenilporfirin, katalaz, yarımkeçirici, smart material.

\section{ИССЛЕДОВАНИЕ КАТАЛАЗНОЙ АКТИВНОСТИ БИОМИМЕТИЧЕСКИХ СЕНСОРОВ ПРИ РАЗЛИЧНЫХ ТЕМПЕРАТУРАХ И КОЛИЧЕСТВАХ СМАРТ МАТЕРИАЛА}

\section{Н.Н.Меликова, Н.И.Али-заде, Т.М.Нагиев}

Разработаны биомиметические сенсоры на основе полупроводника ( $\mathrm{Si}$ ), металла (Al) и смарт материала $\left(\mathrm{TPhPFe}^{3+} \mathrm{OH} / \mathrm{Al}_{2} \mathrm{O}_{3}\right)$. Установлено, что биомиметический сенсор, где в качестве электрода использован полупроводник (Si) проявляет высокие чувствительность, стабильность и воспроизводимость. Изучено влияние температуры и количество смарт материала на каталазную активность биомиметических сенсоров. При исследовании влияния Si-электрода на каталазную активность сенсоров выявлено, что количество смарт материала и температура не влияют на предел обнаружения пероксида водорода в водном растворе, порог чувствительности которого составил $10^{-6}$ масс. \%. При выявлении каталазной активности биомиметического сенсора $\mathrm{TPhPFe}{ }^{3+} \mathrm{OH} / \mathrm{Al}_{2} \mathrm{O}_{3} / / \mathrm{Al}$, было установлено, что его порог чувствительности в таком же растворе также составил $10^{-6}$ масс. \%.

Ключевые слова: биомиметик, сенсор, тетрафенилпорфирин железа, каталазньй, полупроводник, смарт материал. 